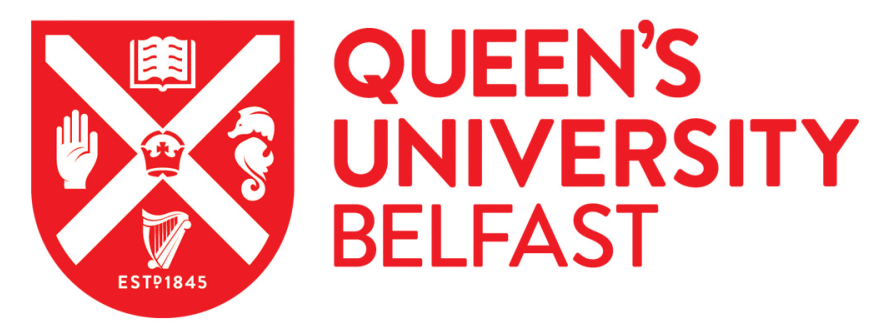

\title{
Practising social work in a context of austerity: experiences of public sector social workers in Greece
}

Pentaraki, M. (2017). Practising social work in a context of austerity: experiences of public sector social workers in Greece. European Journal of Social Work, 1-12. https://doi.org/10.1080/13691457.2017.1369396

\author{
Published in: \\ European Journal of Social Work
}

Document Version:

Peer reviewed version

Queen's University Belfast - Research Portal:

Link to publication record in Queen's University Belfast Research Portal

Publisher rights

(c) 2017 Informa UK Limited. This work is made available online in accordance with the publisher's policies. Please refer to any applicable terms of use of the publisher.

General rights
Copyright for the publications made accessible via the Queen's University Belfast Research Portal is retained by the author(s) and / or other copyright owners and it is a condition of accessing these publications that users recognise and abide by the legal requirements associated with these rights.

Take down policy

The Research Portal is Queen's institutional repository that provides access to Queen's research output. Every effort has been made to ensure that content in the Research Portal does not infringe any person's rights, or applicable UK laws. If you discover content in the Research Portal that you believe breaches copyright or violates any law, please contact openaccess@qub.ac.uk. 


\title{
Practising social work in a context of austerity: experiences of public sector social workers in Greece
}

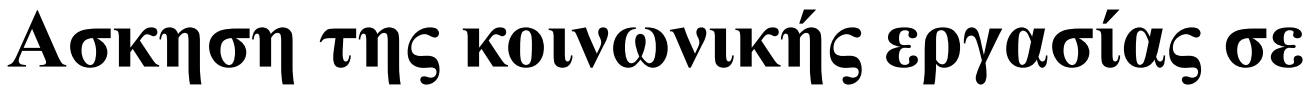

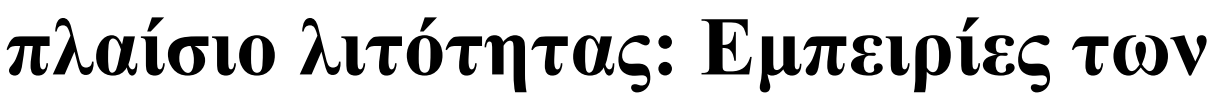

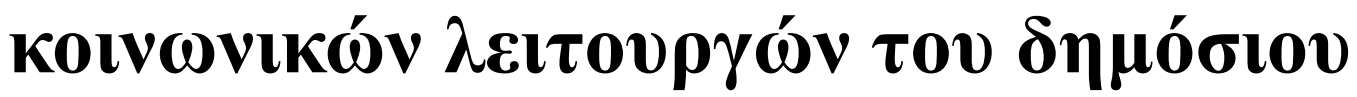

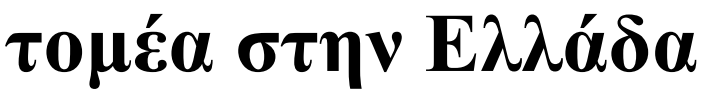

\section{Published in European Journal of Social Work}

Maria Pentaraki

Pages 1-12 | Published online: 31 Aug 2017

- $\quad$ https://doi.org/10.1080/13691457.2017.1369396

\section{- ABSTRACT}

- Since the 1980s and within a context of neoliberal globalization, the welfare state provision in many countries has been affected adversely by austerity and social spending cuts that have intensified since the last global financial crisis of 2008. A country that has been particularly harshly affected is Greece. This paper draws on interviews with public sector social workers in Greece and presents their perceptions of the consequences of austerity/social spending cuts on their work. The research findings of this study suggest that, within the context of austerity, social workers are facing a number of challenges and tensions. The paper argues that these tensions and challenges are local manifestations of the global conditions of neoliberal globalization and as such they have relevance for other countries. Furthermore, it argues that this understanding needs to inform the actions of social workers. It is important for these tensions and challenges to be contextualized within the socio-economic conditions in which they arise in order for austerity and social spending cuts to become a locus of intervention.

- Пврі́ $\lambda \eta \psi \eta$

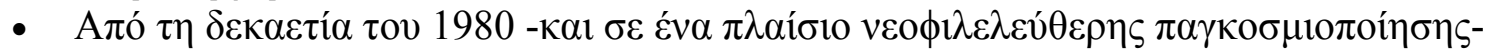

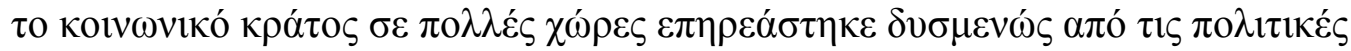

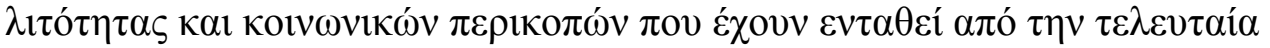

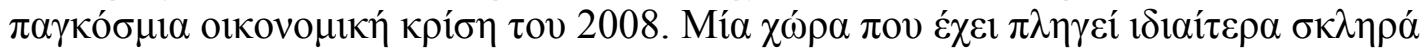

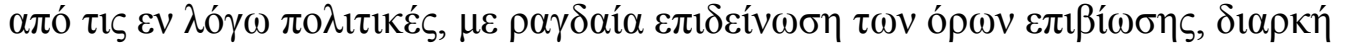

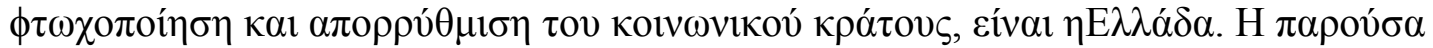

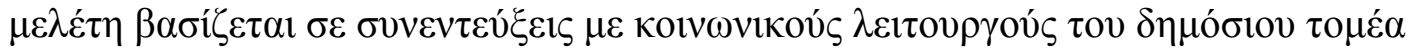

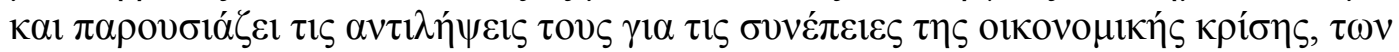




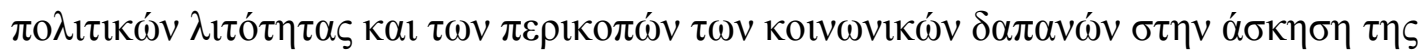

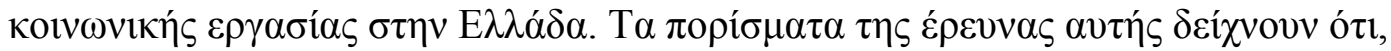

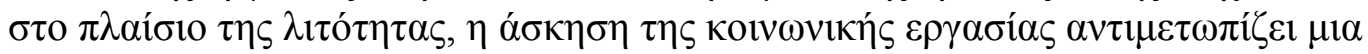

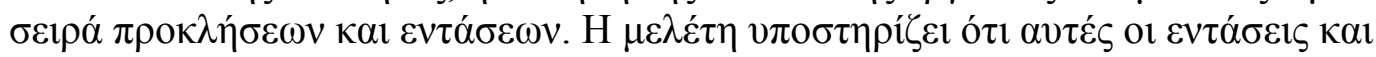

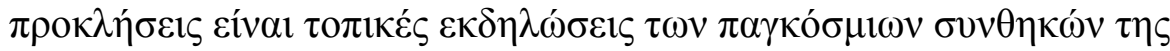

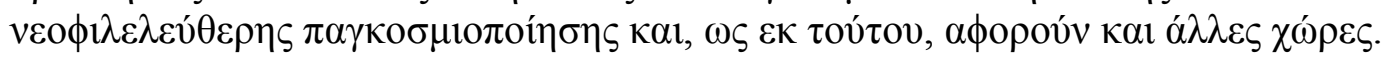

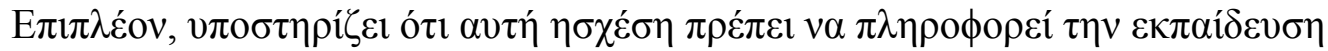

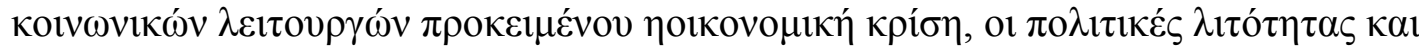

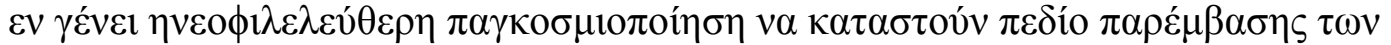

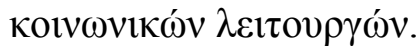

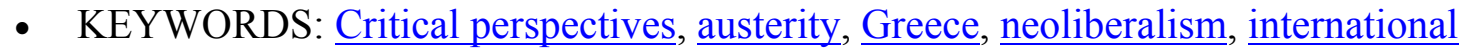
social work

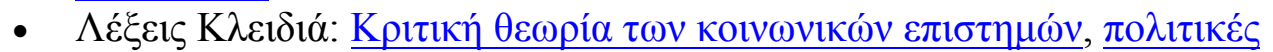

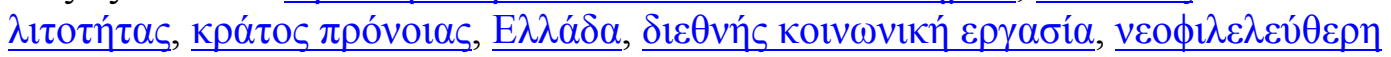

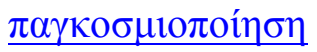

Since the 1980s, welfare state provision in the majority of both developed and developing countries has been affected adversely by austerity/social spending cuts situated within a context of neoliberal globalization ${ }^{\mathrm{i}}$ (Harvey, 2005). These cuts have been intensified since the last global financial crisis of 2008 as the global elite managed to skilfully transform a capitalist crisis into a crisis of public finances, and consequently into a high public debt crisis (HPDC) (Levitas, 2012). This framing legitimized the further neoliberal restructuring of society and its resultant social spending cuts (author's own, Levitas, 2012). A country that has been particularly harshly affected by social spending cuts/austerity measures and neoliberal restructuring is Greece (author's own; Karamesini, 2015; Salomon, 2015; Ioakimidis and Teloni, 2013). While there have been explorations into the impact of the social spending cuts on social work in general, there has not been any empirical work related to the impact of 
the cuts on public sector social workers in Greece. The present research aims to fill this gap by drawing on fourteen in-depth interviews with generalist social workers working in public hospitals and welfare departments in Greece, to explore their perceptions of the consequences of austerity/social spending cuts on their work. The paper is informed by critical theory which, informed by socio-historical context, is oriented towards critiquing and changing society (Kincheloe and McLaren, 2000). This exploration is relevant due to the contextual understanding of social work practice. Social work is a contingent activity, related to the context in which it emerges and operates (Harris, 2008; White, 2000), and as such is influenced by both transformations within the state and wider socio-economic transformations (Parton, 1996).

The impacts of global socio-economic transformations on social work and on the welfare state has been discussed in the international social work literature (among others see Healy, 2008; Sewpaul, 2005; Lorentz, 2005; Dominelli, 2010). This literature has pinpointed neoliberal globalization as a common background for social work practice and has emphasised that an understanding of this is necessary in order to fully grasp issues at a local level (Lorenz, 2005). Thus, before it presents the research study this paper discuss the overall global and national context that the social work profession currently operates.

Socio-economic conditions have deteriorated almost worldwide as a result of the financial crisis (UN, 2014) which has been framed as a crisis of public 
finances in order to legitimize social spending cuts (Levitas. 2012, author's own). Socio-economic inequalities have been rising as global wealth has been concentrated in the hands of $1 \%$ of the population (Dorling,2014) within a background of neoliberal globalization (Harvey, 2005). This growing level of socio-economic inequalities further leads to the intensification of social problems (Wilkinson \& Pickett, 2009). This has been reflected in the rising levels of poverty in European Union (EU) where in 2012, one in four Europeans lived on less than $60 \%$ of median national income and since the start of the crisis, 6.7 million people have been added to this number (European Union, 2014:19)

One country that has faced drastic social spending cuts, ranging from $40 \%$ to $60 \%$, is Greece and this has raised questions about the survival of its welfare state (Petmesidou, Guillén, 2014; Karamesini, 2015). Despite the predominant discourse that blames the people of Greece for the HPDC, and the consequent austerity/social spending cut measures, in essence, HPDC has been a consequence of class-based policies implemented by successive Greek governments. These policies include, one of the lowest corporate taxation rates in the EU (OECD (2010), one of the highest military spending levels worldwide (SIPRI, 2010), and the implementation of a high bank bailout (for a detailed discussion about the factors that led to the HPDC see author's own, 2013). This class based induced HPDC has lead successive Greek governments since 2010 
to agree to loans from the TROICA (European Commission (EC), European Central Bank (ECB) and International Monetary Fund (IMF)) to service it. These loans came attached with numerous conditionalities, part of a structural adjustment program (SAP) ${ }^{\mathrm{ii}}$ aiming to restructure society along neoliberal lines (Karamesini, 2015, author's own). One of the predominant features of these conditionalities has been social spending cuts.

Through the implementation of the social spending cuts socio-economic conditions in Greece have deteriorated rapidly, with the country falling 7 places in the UN's Human Development Index Ranking (UN 2011 \& 2014). These deteriorating conditions (see Bohoslavsky, 2015, Karemesini, 2015, Koukiadaki, \& Lefteris 2012) have led the UN Independent Expert advisor to state that a humanitarian and human rights crisis in the field of economic and social rights exists in Greece (Bohoslavsky, 2015). Furthermore, leading legal scholars (Salomon, 2015) have argued that imposed austerity has led to the denial of social rights and enormous social harm. The deteriorating conditions have put enormous pressures on the Greek welfare state. However, even before the onset of austerity measures the welfare state in Greece was familialist, fragmented and rudimentary (Ferrera, 1996; Petmesisou, 1996) and ill equipped to meet the population's welfare needs. Now, social spending cuts have further undermined even this ability. Currently, the gap between need and provision has increased sharply due to the high level of unemployment (around $30 \%$ on 
average and reaching $65 \%$ among young women), the drastic undermining of welfare provision through the deep social spending cuts implemented by the government (under European Union constraints and the strict loan-deal requirements for Greece) (Petmezidou \& Guillien 2014) and cut backs in the staffing of public services due in part to the SAP policy of hiring one person for every ten retiring. State budget allocations to municipalities have been reduced by $60 \%$ (Karamesini, 2015). This has been critical since municipalities are almost exclusively the providers of welfare provision in the country. Other changes include the abolition of means tested rent subsidy, the reduction of pension benefits, introduction of caps to the duration of unemployment benefits and the restriction of eligibility criteria, such as community care to elderly people. In this case, approximately $30 \%$ to $40 \%$ of previous beneficiaries are now uncovered as only those living with unemployed relatives are included (Karamesini, 2015). At the same time that global neoliberal restructuring undermines welfare provision, rising social problems tend to result in increased demands for social services. Thus, as a result of being a contingent activity (McDonald, Harris, Wintersteen, 2003), social work is greatly influenced by these conditions.

Globally, within the current context of rising inequalities and social spending cuts, social work faces many challenges, tensions, and crises, such as the dismantling, restructuring, and fiscal strangling of its programs (Wallace \& 
Pease, 2011; Baines, MacKenzie Davis \& Saini, 2009; Aronson \& Sammon, 2000). These observations have been detailed in social work scholarly literature (among others, see: Wallace \& Pease, 2011; Ferguson, Lavalette, \& Whitmore, 2005; Baines, MacKenzie Davis \& Saini, 2009; Aronson \& Sammon, 2000; Dominelli, 1999; Fabricant \& Burghardt, 1992). Furthermore, in the UK the demoralization of frontline social workers has been documented (Jones, 2001) and in the US, the proletarization of social work has been noted (Fabricant \& Burghardt, 1992). Social workers in Canada are constrained by time pressures, inappropriate managerial forms, fragmenting effects of divided labour, and stressful and demanding workplaces (Baines, MacKenzie Davis \& Saini, 2009; Aronson \& Sammon, 2000). In Australia, social workers experience ethical and moral dilemmas (McDonald \& Chenoweth, 2009) and in Ghana, social workers report that the chronic underfunding undermines even the most basic activities (Laird, 2008). The professional association of social work in Greece has stated that their members' working conditions have deteriorated (author's own). All these issues identified in various countries cut across national boundaries, since they all emanate from the global neoliberal agenda that undermines welfare provisions (Lorenz, 2005; Healy, 2008; Dominelli, 2010). 
Having briefly outlined the context for the socio-economic transformations and pressures in which social work operates, the article now turns to presenting the research study.

\section{Research $^{\mathrm{i}}$}

This research explores the perceived impact on social work practice of the economic crisis in Greece and its accompanying austerity and social spending cuts. The study is based on the qualitative findings from fourteen in depth interviews with public sector ${ }^{\mathrm{ii}}$ generalist social workers employed in established state mediated settings that have been affected greatly by social spending cuts (i.e. in county welfare departments, municipalities and the hospital social services).

Due to their being no single list of all public sector social workers in Greece, participants in this study had to be chosen through an integrated process of purposeful and snowball sampling. At the start of the process, the author had informal discussions with key informants, such as social work academics and practitioners and members of the committee of the Greek Association of Social Workers. The selection criteria that were presented to the key informants were for social workers who: a) were currently working as public sector social workers, in either the social services of a hospital or welfare office; 2) represented a variety of geographical areas; and 3) had at least two years of 
experience. Based on this, names of some social workers meeting these criteria were proposed, contacted and initial interviews conducted. Subsequently, other participants were identified through snowballing. Participants consented to the interview and were informed about the research, issues related to confidentiality and anonymity and that the content of these interviews might be published. Therefore, to maintain anonymity and confidentiality, details of their geographical location and character of the organization in which they work are presented in broad terms. The appropriate ethical approval was granted by $\mathrm{X}$ university.

All fourteen iv ${ }^{\text {iii }}$ of the public sector social workers interviewed were women, which reflects the disproportional presence of women in the social work profession in Greece as well as elsewhere. They were from five different towns and cities, including Athens, the capital city (that accounts for almost half of the population of Greece). Because of their small size, other geographical areas are not mentioned by name in order to maintain the anonymity of the participants. The interviewees from outside Metropolitan Athens were based in other predominantly urban locations (although also included semi-rural, rural, and other remote settings; such as, islands in their area of social work practice). The interviewees all held permanent public sector jobs. The age profile ranged from the early thirties to early fifties and participants were all white women born in Greece. At their highest level of education, one participant held a Master's degree in Social Work; four participants held two degrees, one of 
which was a social work degree; and the rest held undergraduate degrees in social work. The work experience of the social workers was between three and twenty two years.

The data were collected through the application of qualitative techniques focusing on semi-structured in-depth interviews. The principal question developed in this research was: How has your work been impacted upon by the $\mathrm{SAP} /$ austerity measures? ${ }^{\mathrm{v}}$. The interviewees were provided with the opportunity to elaborate at their discretion. The interviews were carried out in Greek by the author, between September 2010 and December 2010. The majority of the interviews lasted from forty to fifty minutes and were then analyzed thematically to identify, analyze, and report patterns (themes) within the data (Braun and Clarke, 2006).

While it is acknowledged that the small sample and its particular specificities can be a potential limitation, the study offers important insights into the challenges of practicing within the context of austerity. Transferability of these findings can be further strengthened through future larger studies. Also, in a future research there is the potential more quantifiable data to be sought, such as the number and kind of services and service users affected. Additionally, these findings were taken during the first phase of the imposed austerity measures. It will be interesting to carry on the research now that further cuts have been implemented. 


\section{Findings}

The key themes that emerged during the interviews are, 1) changing working conditions characterized by understaffing and increased workload 2) changing working practices that relate to office bound practice and reliance on informal and charitable networks; 3 ) intensification of advocacy (micro acts of ethical resistance in the workplace) and 4) Shared reality between service users and social workers. It should be noted that the categories of these four themes are not clear-cut, since some subthemes run across them. For example, all findings reflect concern for the service users in terms of the respondents' inability to meet their needs in the current context. Social work practice is left under resourced, constricted, and undermined in its efforts to meet the needs of service users effectively. Social work practice in a context of austerity encompasses not only challenges/tensions but also transformative possibilities that are manifested in the micro acts of ethical resistance in the workplace and the acknowledgment of a shared reality between service users and social workers.

\section{Changing working conditions: Increased workload and understaffing}

One theme that emerged from interview responses was the changing of working conditions as a result of the increasing workload and understaffing that resulted from the economic crisis.

As one respondent noted, 
“...there are so many people that have lost their jobs due to the crisis. These are people that desperately try to find another job but there are none. What will happen to them when their unemployment benefits run out? How can we help them? (At that point, a service user knocked on the door; after a brief interruption, the interview resumed.) Just to give you another example, this is an ex business owner, did you notice how expensive his clothes and leather briefcase are? He has nothing now. We see a lot of people like him, whose business bankrupted because of the economic crisis. He lost everything, his house, his business, and he does not have access to health care either, because as a bankrupt business owner, he still owes tax revenue, which means that it is impossible to get access to the health care afforded to destitute people. There are so many people like him who are facing similar problems and come to us...."

The same respondent continued discussing how present socio-economic conditions have undermined the ability of social workers to effectively help people.

"There is not much we can do...we are so overwhelmed with the rising numbers of people who come to us..., we can listen to them but with the absence of resources and benefits they are entitled to there is not much 
we can do, we constantly try to beg for resources from churches. We are constantly on the run".

Additionally, the respondents clearly stated that their ability to effectively help people was negatively impacted by understaffing. Furthermore, pressures caused by the understaffing of social services were exacerbated through the SAP-imposed policy of hiring one civil servant for every five retired during the first phase of the SAP implementation, which was the time when the research was conducted, as well as from the decrease of pension benefits. As a social worker working in a welfare department stated,

"Colleagues near retirement rushed to retire, in order not to face the new regime of lower retirement benefits. My department was understaffed; now, it is even more so... A few of us are left to deal with a continuously increasing caseload and this is not possible. It makes our job impossible. Whatever we do, - however many hours we put in we cannot respond effectively..."

This response clearly highlights the challenge to social workers to respond to more service users with fewer staff.

The participants now find themselves operating with an increased workload, due to the increase in service need and the understaffing that the implementation of SAP has brought. These changes in working conditions reflect overall global changes in the welfare professions along neoliberal lines 
(Baines, et al, 2009). A major characteristic of those changes are the downsizing of the public sector and an increase in poverty (Harvey, 2005).

Thus, the potential contribution of social services to poverty alleviation and welfare provision is seriously handicapped. Similar results in the provision of welfare services have been found in other countries that have implemented IMF-imposed structural adjustment programs (Laird, 2008).

\section{Changing working practices: "Turning the clock back"}

The study participants described the changing nature of their practices in terms of the site of their practice, as well as an over-reliance on charitable networks, both of which denote a "turning the clock back" trend and pose new challenges and tensions to them. This echoes what Wallace and Pease (2011), among others, have described as a "continuing crisis of resourcing and legitimation." Limited resources and changing social policies undermine their ability to engage in meaningful social work practice by leaving the needs of the service users unmet. Interviewees described how their professional practices had become mostly office-bound, due to cuts in travel expenses that in turn have exacerbated geographical inequalities. Rural and remote island areas that do not have social services are now neglected due to the travel expenses reductions. As one interviewee put it, 
"Neither can I go to rural areas nor can our clients travel to us since they cannot even afford the bus fare. It is heartrending to know there are people that cannot even get an initial contact. The money allocated to travel expenses do not even cover one third of the cost..." (Social worker in a municipal welfare department office)

Another social worker from a welfare department based in a city, but having in her jurisdiction remote islands, also explained her current limitation to one annual trip to an isolated island which results in her having to pay part of the expenses accrued from "her own pocket".

Additionally, budget cuts have led to an overreliance to informal, charitable and faith based networks. A social worker in a predominantly rural welfare department office refers to some of her cases as follows, "I have cases of people that require medical treatment and cannot afford the bus fare to go to the hospital. They come to me and I know that if they do not get to the hospital their life is threatened. I am spending so much time trying to locate some money. I am phoning and visiting all the churches in the area and any other potential source I can. Every time I have to resort in begging to manage to get their bus fare."

Social workers' dependence on charitable organizations increases, even though the charitable organizations face budget cuts 
too; in the end, the amount of support they can get from such organizations is very small. Another one stated that it is the states' responsibility to provide funding. Also she stated that "I should not have to resort to begging to try to scrabble some resources together for the service users."

In contrast, all the hospital social workers mentioned that they would obtain funds from the "hospital's church collection box", and thus did not express dismay about their dependence to a faith based source. However, they were concerned that even these funds have decreased considerably, since people do not currently donate much. Meanwhile, they continue to resort to practices of pleading and begging to access resources, either from charities or faith-based organizations. It is interesting to note that the majority of the respondents used the verb "beg" to describe their attempts to locate resources from charitable sources. The use of this verb might acknowledge both the difficulty to draw resources from faith-based organizations, as well as a recognition that the charitable sources of support are not obliged to provide for the needs of the service users. It might also reflect their disquiet that they must secure resources on moral grounds, rather than as part of a social contract. As a social worker working for a welfare department stated, "it is the state's 
responsibility to provide needed resources." The state provision of resources is a component of redistribution, whereas charitable provision of resources is philanthropy. These challenges that are created reflect the diminishing role of state responsibility within the context of neoliberal capitalism.

\section{Restrictions in eligibility criteria, intensification of advocacy and the} emergence of micro acts of ethical resistance in the work place

The participants discussed how the new restricted eligibility requirements emanating from the diminishing role of state responsibility towards welfare not only raised questions of inappropriate ethical practice, but also placed constant tensions and challenges on them that led to an intensification of their practice. This intensification of their practice also offered possibilities of transformation. As one social worker highlighted,

"The director of the welfare department I work in had delivered a one-time aid to people, but once the budget cuts were announced she ordered us to take it back. That has been so unethical. I could not stand seeing service users who really needed it coming back and returning it. I fought with the director but nothing changed. Now I have to fight for each of my cases. I know these people. I know how hard they find it just to get by and 
I cannot accept the imposition of the eligibility criteria on them. There is George, he is an elderly man who lives just around the corner from our office. He has nothing. I know this all too well. How can I go and tell him that he needs to return it..."(Social worker in a welfare department office)

'This statement clearly reflects an on-going tension. The eligibility criteria clearly clash with the values and knowledge that the practitioners have about the needs of their clients. Practicing under austerity measures raises ethical tensions that are related to what social work ought to be and what social work is becoming. These tensions emerge out of the competing objectives among the needs of the service users as known by the practitioners, and the new laws and regulations that have been imposed to determine whose needs are eligible for state support. This state redefinition (or Troika imposed redefinition) of "eligible needs" contradicts the professional knowledge of the social workers about the needs of their service users, and becomes a barrier to the use of professional knowledge (McDonald, et al, 2008). This constitutes a tension between needs driven and resource driven practice.

\section{Proletarization of social workers: Acknowledged shared reality.}

The decrease in wages that was imposed by the SAP has undermined the middle class status of social work professionals that has resulted in their proletarization, 
a new development within the context of austerity. This proletarization poses not only a challenge but also a possibility of transformation, since it has given some of them new insights about the connections between themselves and the service users. This theme has been described in more detail elsewhere (author's own) “As one of the interviewed social workers stated (author's own),

"The money I am making is not enough. I am making 830 euros a month, after I pay rent and the utilities bills there is no money left. A lot of our colleagues face a similar situation. Can you believe that I already have three offers from colleagues to become roommates? No one from our office had money to go for vacations. I feel very close to being a service user." (Social worker in a welfare department office)

The findings show that social workers are also affected adversely by the austerity context. It can be argued that service users and social workers have a shared reality. The concept of shared reality refers to situations in which the social worker helps the service user deal with the adverse consequences of a socio-economic reality that they themselves also experience. Up to now the phenomenon of shared reality has been used to describe the dynamics characterizing relationships of professionals providing help in the emergency phase and relationships of professionals conducting ongoing psychotherapy 
(Brown, 2010). Now it can be used to describe the professional working within an austerity context (author's own). 


\section{Discussion of findings}

This research has been informed by critical social theory (Kincheloe and McLaren, 2000), which is concerned with unravelling the operation and the impact of oppressive structures, such as social spending cuts/austerity measures within the context of neoliberal globalization. Accordingly, this paper has examined the perceived impact of austerity/social spending cuts and its accompanying consequences, on public sector social workers.

The findings present a picture of public sector social workers who currently face many challenges, tensions, conflicts and ambiguities, such as underfunding, understaffing, overwork, heavy case loads, overreliance on charitable structures, office-bound practice, and proletarization. The main underpinning challenge is the inability of social workers to act effectively (Wallace \& Pease, 2011; Baines, MacKenzie Davis \& Saini, 2009; Aronson \& Sammon, 2000; Fabricant \& Burghardt, 1992) due to the consequences of the current socio-economic context of neoliberalism (Harvey, 2005). Overall, these challenges/tensions arise from the diminishing role of state responsibility during the neoliberal phase of capitalism in the social and personal well-being of people (Harvey, 2005). These social spending cuts have forced social workers into more office bound practice and to increasing their reliance on charitable sources of support. The latter has been suggested in developed welfare states 
such as in Sweden (Jonsson, 2014). These practices imply a return to the philanthropy and religious ideologies of a traditional system of 'poor relief' and charity work rather than full provision within a contemporary social service system (Jonsson, 2014:26). The majority of tensions experienced are magnified because of the clash between a needs driven practice and an austerity limited resource driven practice, as reflected in the tensions between professional knowledge, skills and values, and neoliberal state mandated practices. The tensions that emerge out of this clash can offer the potential of transformation as social workers' knowledge of need becomes the framework out of which they intensify their advocacy role (as in "I fight for every case") on behalf of the service users. The participants described fighting with managers in order to overturn the implementation of the restricted eligibility criteria. This intensification of their advocacy role echoes not only what has been described as 'ethics work' (Banks, 2009; Colley, 2010), referring to the labour needed to maintain an ethical stance (Colley, 2012), but it also can be seen as micro acts of work place resistance against the neoliberal redefinition of eligible needs. These two concepts together encompass "micro acts of ethical resistance" in the workplace, since they are informed by the ethics of the profession to meet the best interests of the service users.

Thus, these challenges/tensions pose not only difficulties but also present possibilities for transformation, as the micro acts of ethical resistance in the workplace and the acknowledged shared reality of social workers between 
themselves and service users reveal. These micro acts of ethical resistance reflect the agency of the social workers in reaction to oppressive policies. Furthermore, they signify the political context and dimensions of ethical social work practice.

Other scholars researching ethical issues have argued that practitioners must decide whether to pursue conscientious objection, compliance, or adopt a stance of "principled infidelity" (Wallace \& Hoyle, 2007, pp.75). Similarly, Dominelli (1999) presents three options for social workers when faced by the structural barriers posed by neoliberal globalization. These are "accommodation, escapism or resistance" (pp.20). The present findings suggest the possibility of resistance at the micro level, and reflect discussions by other social work scholars (among others see White, 2009). However, it remains to be seen, whether the ethical tensions that inform these acts can be transformed into the "social work of macro resistance" beyond the ranks of a small number of politically committed social workers, or if they will result in a detachment and a distancing of the social workers, as suggested by Jones (2001). Clearly, the study participants were very much concerned about what was happening to the service users they worked with. This was suggested by the increased advocacy efforts that were reported, and the tears that filled the eyes of many respondents at times during the interviews when they talked about their struggle to address the needs of the service users. Thus, the detachment that Jones (2001) refers to is not detected in the present findings. 
Even though there is a political dimension to these micro acts of ethical resistance as they present transformative possibilities, by themselves they cannot overthrow the context of austerity without being linked into broader movements for change (White, 2009).

\section{Conclusions}

To conclude, this paper has documented the tensions and challenges that social workers face while practicing in Greece in a context of austerity. These accord with similar tensions and challenges that have been reported in other countries also experiencing the impacts of austerity and neoliberalism (Wallace \& Pease, 2011; Ferguson, Lavalette, \& Whitmore, 2005; Baines, MacKenzie Davis \& Saini, 2009; Aronson \& Sammon, 2000; Dominelli, 1999; Fabricant \& Burghardt, 1992). Thus, the shared context of austerity and neoliberalism presents a common context for the practice of social work in an interdependent world and contributes to the scholarly body of international social work in its attempts to report and understand the effects of neoliberal globalization.

Since as Lorenz (2005) has argued, in order to fully understand local developments, it is imperative to position them within an international framework as "all social work is enmeshed in global processes of change" (Lorenz 97:2 cited in Healy 2008). 
What social workers in Greece face is a local manifestation of the adverse effects of neoliberal capitalism. This paper suggests that this understanding is important in order to engage with the question of neoliberal globalization. Available research (Findlay, McCormack, 2007, Author's own 2015) suggests that social workers do not readily understand the links between local issues and global conditions.

Social workers need to become aware of how the local conditions that they face are influenced by global transformations so that they can develop action at local and global levels (Findlay, McCormack, 2007; Iffe, 2000). Furthermore, they need to be able to analyze social spending cuts and their resultant tensions and challenges as intrinsically politically motivated events that necessitate political changes. This is in line with critical social theory that asserts that in raising awareness of oppressive structures, possibilities of social change are revealed. Without the knowledge of the wider social transformations as the cause of these tensions, there is the danger that social workers experiencing them might become demoralized, internalize self-blame, become overstressed, burned out and consequently become disengaged. This is in line with critical social theory that asserts that in raising awareness of oppressive structures, possibilities of social change are revealed.

However, as I have argued elsewhere, (2013), raising consciousness through enlightened reasoning is important, it is not sufficient to mobilize 
people to engage in social struggles which challenge the neoliberal restructuring of society, since there are other factors that can play a mitigating role in participating, or not, in collective struggles.

Some of these factors can be practitioners' personal and political values, their motivations for joining the social work profession, their understanding of the issues that service users and they themselves face, as well as the material conditions of their lives. All these can be explored in future research.

This paper aims to facilitate an understanding that localized challenges are part of neoliberal global consequences. Thus, it resonates with critical and international social work theory and practice attempts to respond to challenges emerging from neoliberal globalization (Ferguson, 2008; Jonsson, 2014; Dominelli, 2010; Midgely, 2001; Author's own) This understanding does not assume to be the sole solution to the negative impacts of neoliberalism. It can be though one of those critical theoretical resources (Garrett, 2015; Gray and Webb, 2013) available to social work in order to address the negative impact of neoliberalism. Furthermore, it may facilitate the social work profession's ability to take part in the 'war of position' (author's own2013; Garrett, 2015) to assert the needs of society over those of the capital (author's own). After all, the global definition of social work, adopted in 2014 by IFSW and IASSW, reflects a profession aspiring to work towards goals of social justice. It is up to us, those 
professionals who still believe in the social justice mandate of our profession, through a broad coalition building across local, national and international lines, to translate this mandate into effective policies and furthermore develop a society organized along equality rather than along the needs of the market. 


\section{References}

Abramovitz, M. (2005). The largely untold story of welfare reform and the human services. Social Work, 50(2), 175-186. doi: 10.1093/sw/50.2.175

Aronson, J. \& Sammon, S. (2000). Practice amid social service cuts: Working with the contradictions of "small victories". Canadian Social Work Review, 17(2), 167-187.

http://www.jstor.org/stable/41669704?seq=1\#page_scan_tab_contents

Baines, D.; MacKenzie Davis, J.; Saini, M. (2009). Wages, working conditions, and restructuring in Ontario's social work profession. Canadian Social Work Review / Revue canadienne de service social, 26 (1), 59-72. http://www.jstor.org/stable/41669902?seq=1\#page_scan_tab_contents

Baum, N (2010). Shared traumatic reality in communal disasters: toward a conceptualization. 
Psychotherapy: Theory, Research, Practice and Training, 47(2), 249-59. http://dx.doi.org/10.1037/a0019784

Braun, V. and Clarke, V. (2006) Using thematic analysis in psychology. Qualitative Research in Psychology, 3 (2). pp. 77-101. http://dx.doi.org/10.1191/1478088706qp063oa

Buila, S. (2010). The NASW code of ethics under attack: A manifestation of the culture war within the profession of social work. Journal of Social Work Values and Ethics, 7(2), 1-8.

Dominelli, L. (2010). Social Work in a globalizing World. Cambridge: Polity Press.

Dominelli, L. (2007). " Contemporary challenges to social work education in the United Kingdom". Australian Social Work 60(1), 29-45. DOI: $10.1080 / 03124070601166695$

Dominelli, L. (1999). Neo-liberalism, social exclusion and welfare clients in a global economy. International Journal of Social Welfare, 8(1), 14-22. DOI: $10.1111 / 1468-2397.00058$

Dorling, D. (2014). Inequality and the 1\%. Verso Books. 
European Commission (2013). Social Protection Budgets in the Crisis in the EU. Brussels: European Commission.

European Union (2014) Social Europe: Annual Report of the Social Protection Committee on the Social Situation in the European Union. Luxembourg: European Union.

Eurostat. (2013). Eurostat newsrelease/euroindicators: Euro area unemployment rate at 11.7\% . Retrieved January 2013 from: http://epp.eurostat.ec.europa.eu/cache/ITY PUBLIC/3-01022013-BP/EN/301022013-BP-EN.PDF

Eurostat. (2011a). Total expenditure on social protection per head of population. Retrieved March 2011 from:

http://epp.eurostat.ec.europa.eu/tgm/table.do?tab=table\&init=1\&plugin=1\&lang uage $=$ en $\&$ pode $=\operatorname{tps} 00100$.

Eurostat. (2011b). Living conditions statistics. Retrieved March 2011 from: http://epp.eurostat.ec.europa.eu/statistics_explained/index.php/Living_condition s statistics. 
Eurostat. (2009). Population and social conditions. Retrieved January 2013 from: http://epp.eurostat.ec.europa.eu/cache/ITY OFFPUB/KS-SF-09053/EN/KS-SF-09-053-EN.PDF

Fabricant, M. B. \& Burghardt, S. (1992). The welfare state in crisis and the transformation of social service work. New York: M. E. Sharpe.

Ferguson, I., (2008). Reclaiming social work: Challenging neoliberalism and promoting social justice. London: Sage.

Ferguson, I., \& Woodward, R. (2009). Radical social work in practice: Making a difference. Bristol: The Policy Press.

Ferguson, I. , \& Lavalette, M. (2006). Globalization and global justice: Towards a social work of resistance. International Social Work, 49(3), 309-318. doi: $10.1177 / 0020872806063401$

Ferguson, I., Lavalette, M. , \& Whitmore, E. (Eds.) (2005). Globalisation, global justice and social work. London: Routledge. 
Ferrera, M. (1996) "The "southern model" of welfare in social Europe". Journal of European Social Policy 6 (1): 17-38. doi: 10.1177/095892879600600102

Findlay, M., \& McCormack, J. (2007). "Globalization and social work education and practice: Exploring Australian practitioners' views". Journal of Sociology \& Social Welfare, 34, 123-142.

Fook, J. (2010). Social work: Critical theory and practice. London: Sage Publications.

Garrett, M. P. (2015) 'Introducing Michael Gove to Lo1"c Wacquant': why social work needs critical sociology. British Journal of Social Work (2015) 117 Advance Access published April 14, 2015 doi:10.1093/bjsw/bcv024 www.basw.co.uk

Gray, M. and Webb, S. A. (2013) 'Towards a "new politics” of social work', in M. Gray and S. A. Webb (eds). The new politics of social work. Houndsmill: Palgrave.

Harris, J. ( 2008). “State social work: Constructing the present from moments in the past". British Journal of Social Work, 38(4), 662-679. doi: 10.1093/bjsw/bcn024 
Harvey, D. (2007). Neoliberalism as creative destruction. The Annals of the American Academy of Political and Social Science, 610(1), 21-44. doi: $10.1177 / 0002716206296780$

Harvey, D. (2005). A Brief history of neoliberalism. Oxford: Oxford.

Healy, L. (2008) International Social work: Professional Action in an Interdependent World. $2^{\text {nd }}$ ed New York: Oxford University Press.

Jones, C. (2001). Voices from the front-line: State social workers and New Labour. British Journal of Social Work, 31, 547-62. doi: 10.1093/bjsw/31.4.547

Jones, C. , \& Novack, T. (1999). Poverty, welfare and the disciplinary state. London: Routledge.

Jones, T. (2015). Six key points about Greece's debt. Jubilee Debt Campaign. Available at: http://jubileedebt.org.uk/reports-briefings/briefing/six-key-pointsgreek-debt-weeks-election

Jönsson, J. H. (2014). Localised Globalities and Social Work: Contemporary Challenges.Unpublished Ph.D Mid Sweden University, Faculty of Human 
Sciences, Department of Social Work.URN: urn:nbn:se:miun:diva-21587ISBN:

978-91-87557-30-9OAI: oai:DiVA.org:miun-21587DiVA: diva2:705444

Ife, J. (2000). "Localized needs and a globalized economy: Bridging the gap with social work practice". Canadian Social Work, 2, 1, 5064.

Ioakimidis, V., \& Teloni, D. D. (2013). Greek social work and the never-ending crisis of the welfare state. Critical and Radical Social Work, 1(1), 31-49.

Ioakimidis, V., Cruz Santos, C. \& Martinez Herrero, I. (2014).

Reconceptualizing social work in times of crisis: An examination of the cases of Greece, Spain and Portugal. International Social Work 2014, doi:

10.1177/0020872814524967 Vol. 57(4) 285-300

Karamessini, M. (2015). The Greek social model: Towards a deregulated labour market and residual social protection in Daniel Vaughan-Whitehead (ed) The European Social Model in Crisis: Is Europe Losing Its Soul?, Cheltenham: EdwardElgar Publishing, 230-288.

Kincheloe, J. L. , \& McLaren, P. (2000). Rethinking critical theory and qualitative research. In N. K. Denzin and Y. S. Lincoln (eds), Handbook of qualitative research (2nd ed., pp 279 314). Thousand Oaks: Sage.

Khan, P., \& Dominelli, L. (2000). The impact of globalization on social work in the UK. European Journal of Social Work, 3(2), 95-108. DOI: $10.1080 / 714052817$ 
Koukiadaki, A. and Lefteris K. (2012) "Opening Pandora's Box: the sovereign debt crisis and labour market regulation in Greece." Industrial Law Journal 41,(3): 276-304.

doi: 10.1093/indlaw/dws031

Levitas, R. (2012). “The Just's Umbrella: Austerity and the Big Society in Coalition policy and beyond". Critical Social Policy, 32(3) 320-342 doi: $10.1177 / 0261018312444408$

Lorenz, W (2005). Social work and a new social order-challenging neoliberalism's erosion of solidarity Social work \& society 3 (1), 93-101 Available at:http://www.socwork.net/sws/article/view/205/475

MacLeavy, J. (2010). Remaking the welfare state: From safety net to trampoline. In K. Birch and V. Mykhnenko (eds.). The rise and fall of neoliberalism: the collapse of an economic order?( pp. 133-150). New York: Zed Books.

McDonald, A., Postle, K., \& Dawson, C. (2008). Barriers to retaining and using professional knowledge in local authrotiy social work practice with adults in the UK. British Journal of Social Work, 38 (7), 1370-1387. doi: 10.1093/bjsw/bcm042 
McDonald C., Harris J., Wintersteen R. (2003). Contingent on context? Social work in Australia, Britain, and the USA. British Journal of Social Work 33(2):191-208. doi: 10.1093/bjsw/33.2.191

Midgley, (2001). " Issues in international social work.

Resolving critical debates in the profession".

Journal of Social Work 1 (1): 21-35. doi: 10.1177/146801730100100103

Mishra, R. (1999). Globalization and the welfare state. Cheltenham: Edward Elgar.

OECD. (2010). Corporate income tax rate/Corporate and capital income taxes, in OECD TAX Data Base. Retrieved April 2011 from:

http://www.oecd.org/document/60/0,2340,en_2825_293564_1942460_1_1_1_1 ,00.html\#C CorporateCaptial.

Parton,, N (1996). Social theory, social change and social work. London: Routledge.

Patton, M. Q. (2002). Qualitative research and evaluation methods, 3rd edn. Thousand Oaks, CA: SAGE. 
Petmesidou, M., Guillén, A. M. (2014). Can the welfare state as we know it survive? a view from the crisis-ridden south European periphery. South European Society \& Politics,19(3): 295-307.

DOI:10.1080/13608746.2014.950369

Petmesidou, M. (1996). 'Social protection in Greece : a brief glimpse of a welfare state'. Social Policy and Administration 30 (4):324-347.

DOI:10.1111/j.1467-9515.1996.tb00564.x

Reisch, M. (2013). "Social work education and the neo-liberal challenge: The US response to increasing global inequality". Social Work Education: The International Journal, 32(6), 715-733. DOI:10.1080/02615479.2013.809200

Reisch, M \& Staller, K (2011). “ Teaching social welfare history And social welfare policy from a conflict perspective". Journal of Teaching in Social Work, 31:2,

131-144

http://dx.doi.org/10.1080/08841233.2011.562134

Reisch, M., Andrews, J., (2002). The road not taken: a history of radical social work in the United States. New York: Brunnel- Routledge.

SIPRI (2010) SIPRI Yearbook 2010. Armaments, Disarmament and International Security. Oxford: Oxford University Press. 
Salomon, M. E. (2015). "Of austerity, human rights and international institutions". European Law Journal 21,(4): 521-545. doi 10.1111/eulj.12138 Sewpaul, V. (2006). "The global-local dialectic: challenges for African scholarship and social work in a post-colonial world". British Journal of Social Work, 36(3), 419-434. doi: 10.1093/bjsw/bcl003

Smith Rotabi, K., Gammonley, D., Gamble, D. N., \& Weil, M. O. (2007). Integrating globalization into the social work curriculum. Journal of Sociology \& Social Welfare, 34, 165-185.

Stiglitz, J. E. (2002). Globalization and its discontents. New York: W.W. Norton.

United Nations. (2010). Human development report. Retrieved April 2011 from: http://hdr.undp.org/en/reports/global/hdr2010/.

United Nations. (2014). Human development report. Retrieved March 2015 from: http://hdr.undp.org/en/2014-report

Wallace, J., \& Pease, B. (2011). Neoliberalism and Australian social work: Accommodation or resistance. Journal of Social Work, 11(2), 132-142. doi: $10.1177 / 1468017310387318$ 
Wallace, M. and Hoyle, E. (2007). An ironic perspective on public service change in Managing Change in the Public Services, p.75-94. Oxford:

Blackwell publishing.

Wilkinson, R., \& Pickett, K. (2009). The spirit level: Why more equal societies almost always do better? London: Allen Lane

White, V. (2009). Quiet challenges? Professional practice in modernised social work. In J. Harris \& V. White (Eds.), Modernising social work: Critical considerations (pp. 129-144). Bristol, England: Policy Press.

\section{Notes}

I. In this paper, neoliberalism is understood to refer to the world-wide economic and political trends, predominant since the 1970s, which claim that human well-being can be best advanced through an unregulated market (Harvey, 2005). However, in the last thirty years, human well-being has not generally advanced since inequalities have increased in the majority of the countries worldwide (OECD, 2015).

II. The SAP comprised, amongst other things, deregulation of labour relations, undermining of collective bargaining, decrease of wages and pensions, privatization of state assets, dismantling of the social security system (Karamesini, 2015)

III. iThis is a segment of a larger research project that examines the consequences of the SAP to the Greek Welfare State and the response of the social work profession. Other segments of the social work profession have been interviewed too.

IV. The interviewees worked in centrally planned services until December 2010. After that a process of devolution was imposed. 
V. SAP and austerity measures were both used because the austerity measures were implemented as a result of the SAP imposed. 